\title{
LA EJECUCIÓN DE ACTOS DAÑOSOS COMO FUNDAMENTO DE EXTINCIÓN DEL CONTRATO DE TRABAJO*
}

\section{Pedro IRUReTa URIARTE**}

REsumen: El Código del Trabajo chileno establece como causa de extinción del contrato la realización por parte del trabajador de actos que provoquen perjuicio al empleador. Tradicionalmente, esta causa de despido se ha vinculado con los actos de sabotaje. No obstante, un análisis más acabado de la causal permite concluir que la norma del artículo $160 \mathrm{~N}^{\circ} 6$ CT está más relacionado con la ejecución de actos que supongan daño al patrimonio del empleador. Estos daños no suponen necesariamente la ocurrencia de un delito penal; por el contrario, la figura laboral es más amplia y omnicomprensiva tanto de las alteraciones en la sustancia como en el valor de uso de los bienes cuya titularidad le corresponde al empleador.

PALABRAS CLAVE: Despido - daños - sabotaje - perjuicio - contrato de trabajo

\section{AN EMPLOYEE'S HARMFUL ACTIONS AS A BASIS FOR THE TERMINATION OF AN EMPLOYMENT CONTRACT}

ABSTRACT: The Chilean Labour Code establishes as a cause for termination of an employment contract actions by the employee that cause harm to the employer. Traditionally, this cause for dismissal has been linked to sabotage. However, a closer analysis of this cause of action reveals that Article 160 No. 6 of the Labour Code is more comprehensively related to any acts resulting in damage to employer property. These damages do not necessarily assume the occurrence of a

Abreviaturas: AL (Actualidad Laboral); CAP (Corte de Apelaciones); CP (Código Penal); CPR (Constitución Política de la República); CS (Corte Suprema); CT (Código del Trabajo); GJ (Gaceta Jurídica); RCHD (Revista Chilena de Derecho); RDJ (Revista de Derecho y Jurisprudencia y Gaceta de los Tribunales); REDT (Revista Española de Derecho del Trabajo); RFM (Revista Fallos del Mes); RPS (Revista de Política Social).

Fecha de recepción: 8 de abril de 2013.

Fecha de aceptación: 13 de septiembre de 2013.

** Licenciado en Derecho por la Pontificia Universidad Católica de Chile, y Doctor en Derecho por la Universidad Complutense de Madrid, Profesor de Derecho del Trabajo de la Universidad Alberto Hurtado. Correo electrónico: piruret@uahurtado.cl 
criminal offense. Instead, this measure is broader and encompasses both, the substantive damage to property and also damage to the use value of the employer's property.

KEY WORDS: Dismissal - damages - sabotage - harm - work contract

\section{I) INTRODUCCIÓN}

En una clara repetición histórica de las primeras leyes sociales, el Código del Trabajo chileno ha mantenido una causal de despido disciplinario vinculada a los perjuicios realizados por el trabajador en contra del empleador. En efecto, y estableciendo una referencia obligada a supuestos de buena fe subjetiva, el artículo $160 \mathrm{~N}^{\circ} 6 \mathrm{CT}$ sanciona con el término inmediato del contrato de trabajo el "perjuicio material causado intencionalmente en las instalaciones, maquinarias, herramientas, útiles de trabajo, productos o mercaderías". Se trata de una norma amplia, que pone el acento en la intencionalidad, y que pretende sancionar los perjuicios que sufra el empleador a raíz de las acciones dolosas del trabajador. Curiosamente, más que buscar el resarcimiento de los daños provocados, o de fomentar el cumplimiento forzoso de la obligación, el texto laboral opta por dotar al contratante perjudicado de herramientas jurídicas que le permiten extinguir de forma inmediata el vínculo laboral ${ }^{1}$. De esta manera, el Código fija en el ámbito extintivo la responsabilidad que le corresponde al trabajador por los perjuicios que su conducta le causa al empleador.

La causal antes referida ha tenido un nulo desarrollo doctrinario y jurisprudencial en el Derecho chileno. No solo no existen fallos significativos que hayan desarrollado el núcleo definitorio de la conducta prohibida, sino que tampoco la dogmática nacional ha asumido la necesidad de estudiar a fondo los alcances de esta figura. Más aun, la mayor parte de los textos generales en Chile se limitan a señalar que esta causal se vincula con las figuras propias del sabotaje, sin aportar mayores antecedentes sobre la naturaleza jurídica que subyace en la infracción ${ }^{2}$.

1 Goerlich Peset, José María (2011), "Particularidades de la responsabilidad indemnizatoria del trabajador por los daños causados a la empresa en el desarrollo de la prestación laboral: un intento de explicación”. REDT N ${ }^{\circ} 152$, pp. 945-972, pp. 950 y ss.

2 Véase, por ejemplo y entre otros, Thayer Arteaga, William, y Novoa Fuenzalida, Patricio (1998), Manual de Derecho del Trabajo, T. III. Editorial Jurídica de Chile, $3^{a}$ edición. Santiago: 335 pp., p. 59; Walker Errázuriz, Francisco (2003), Derecho de las Relaciones Laborales, $1^{a}$ edición. Santiago: Editorial Universitaria, 718 pp., p. 409; Soto Calderón, Juan Carlos (1961), Derecho Penal del Trabajo. Santiago: Editorial Jurídica de Chile, 161 pp., p. 121; Gamonal Contreras, Sergio, y Guidi Moggia, Caterina (2011), Manual de Contrato de Trabajo. Santiago: Abedelo Perrot/LegalPublishing Chile, 337 pp., p. 288; y Lizama PorTaL, Luis (2003), Derecho del Trabajo. Santiago: LexisNexis, 224 pp., p. 182. La asimilación de la causal con las figuras de sabotaje también ha sido recogida por la jurisprudencia. En 
Desde luego, la redacción actual de la causal es bastante más amplia que el sabotaje, más aun si se considera que tradicionalmente parte de la dogmática laboral vinculaba esta última figura solo con aquellos actos destinados a presionar al empleador a objeto de alcanzar determinados beneficios $^{3}$. Por el contrario, la configuración que subyace en el artículo $160 \mathrm{~N}^{\circ} 6$ CT es más extendida y compleja, avanzando desde la mera comisión de un delito hacia otras alternativas de infracción a la buena fe contractual $^{4}$.

Según se ha dicho, la causal tiene una fuerte raigambre histórica. En efecto, el artículo $5^{\circ} \mathrm{N}^{\circ} 7$ de la Ley $\mathrm{N}^{\circ} 4.053$ (de 1924) ya estipulaba que el contrato de trabajo terminaba por "un perjuicio material causado

esa línea, por ejemplo, sentencia de la Corte de Apelaciones de Santiago. 26 de julio de 1984. Rol No D-977-84-T. Recurso de Apelación. Caratulado "Catricura con Planificadora Huelén”. GJ No 49 (1984), p. 168: “1 (...). La letra y el espíritu de ese precepto (...) la asimilan a una acción de sabotaje, esto es, perjudicar al patrono maliciosamente por entorpecimiento de la actividad laboral que, así, se menoscaba o cesa, o provocando desperfectos en talleres y maquinarias que, a la postre, conducen al mismo mal (...)"; sentencia de la Corte de Apelaciones de La Serena. 24 de diciembre de 2010. Rol N 154-2010. Recurso de Nulidad. Caratulado "Meriño Alfaro con Vicencio Auger Limitada". Disponible en www.poderjudicial.cl: "Quinto: Que respecto de la causal invocada por la demandada, contemplada en el artículo $160 \mathrm{~N}^{\circ} 6(\ldots)$. Esta causal es asimilada al sabotaje, que consiste en querer perjudicar al empleador maliciosamente por entorpecimiento de la actividad laboral, la cual se menoscaba o cesa"; y sentencia de la Corte de Apelaciones de Antofagasta. 10 de agosto de 2011. Rol N ${ }^{\circ}$ 145-2011. Recurso de Nulidad. Caratulado "Saavedra Zepeda con Ameco S.A.”. Disponible en www.poderjudicial.cl: “Sexto: Que el artículo $160 \mathrm{~N}^{\circ} 6$ del Código del Trabajo dispone que él contrato de trabajo termina sin derecho a indemnización alguna cuando el empleador le ponga término invocando una o más de las siguientes causales: 6 . El perjuicio material causado intencionalmente en las instalaciones, maquinarias, herramientas, útiles de trabajo, productos o mercaderias', de donde fluye que se trata de hechos graves, que implican la idea de un sabotaje por parte del trabajador (...)".

3 Gaete Berríos, Alfredo (1966), Tratado de Derecho del Trabajo y Seguridad Social, T. III. Santiago: Editorial Jurídica de Chile, 213 pp., p. 151. Como se puede observar, se trataba de una configuración bastante restringida de esta causal pues la doctrina de la época no la aplicaba a aquellos casos en que el saboteador hubiese estado motivado por un simple interés de perjudicar (sin esperar beneficios de esa conducta).

4 En el propio Código del Trabajo, existen otras referencias legales que complementan la hipótesis que subyace en la causal. Por ejemplo, el artículo $388 \mathrm{CT}$, letra b), considera que el trabajador incurre en prácticas desleales durante el proceso de negociación colectiva cuando ejerza "fuerza física en las cosas". En otros casos, el Código acepta la eventual ocurrencia de perjuicios, y regula los alcances del mismo. Así ocurre en el artículo 380 CT: "Si se produjere una huelga en una empresa o predio, o en un establecimiento cuya paralización provoque un daño actual e irreparable en sus bienes materiales (...), el sindicato o grupo negociador estará obligado a proporcionar el personal indispensable para la ejecución de las operaciones cuya paralización pueda causar este daño"; en el artículo 29 CT: "Podrá excederse la jornada ordinaria, pero en la medida indispensable para evitar perjuicios en la marcha normal del establecimiento o faena, cuando sobrevengan fuerza mayor o caso fortuito, o cuando deban impedirse accidentes o efectuarse arreglos o reparaciones impostergables en las maquinarias o instalaciones"; o en el artículo 171, inciso final: "Si el trabajador hubiese invocado la causal de la letra b) o f) del número 1 del artículo 160, falsamente o con el propósito de lesionar la honra de la persona demandada y el tribunal hubiese declarado su demanda carente de motivo plausible, estará obligado a indemnizar los perjuicios que cause al afectado". 
intencionalmente durante o con ocasión de la ejecución del contrato". Y a partir de dicho texto legal, y con redacciones más o menos similares, se mantuvo legislativamente como causa de extinción imputable al trabajador hasta la dictación del Decreto Ley $N^{\circ} 2.200$ (de 1978) ${ }^{5}$. Este último cuerpo legal eliminó derechamente esta causal y la reemplazó por otras que, manteniendo la hipótesis extintiva, ampliaba los supuestos y los terminaba vinculando con conductas de un claro carácter extralaboral (sin perjuicio que, en algunos casos, la figura se asociaba a cuestiones de orden público general). De esta manera, el contrato de trabajo terminaba por "atentado contra los bienes situados en la empresa" (causal 2a art. 15 DL $2.200)$, por "comisión de actos que produzcan la destrucción de materiales, instrumentos o productos de trabajo o mercaderías, o disminuyan su valor o causen su deterioro" (causal $3^{\mathrm{a}}$ art. 15 DL 2.200), y por "incitación a destruir, inutilizar o interrumpir instalaciones públicas o privadas, o la participación en hechos que las dañen" (causal 5a art. 15 DL 2.200). Todas estas figuras fueron mantenidas en el Código del Trabajo de 1987, y claramente se encontraban imbuidas de un criterio más bien intimidatorio que sobrepasaba el ámbito propio de las relaciones laborales.

La lógica anterior fue superada con la dictación de la Ley $\mathrm{N}^{\circ} 19.010$ (de 1990). En razón de lo anterior, todas las causales del Decreto Ley $\mathrm{N}^{\circ}$ 2.200 a las cuales se ha hecho referencia (y que habían sido incorporadas en el artículo 157 del Código del Trabajo de 1987) fueron derogadas en atención a que respondían a cuestiones más vinculadas al orden penal o extralaboral ${ }^{6}$. En un sistema democrático de relaciones laborales, normas de esta naturaleza simplemente no tienen cabida ${ }^{7}$. Fue así como la nueva legislación del año 1990 reincorporó dos nuevos tipos de causales, que en su momento habían sido establecidas la Ley $\mathrm{N}^{\circ}$ 16.455: "actos omisiones o imprudencias temerarias que afecten a la seguridad o al funcionamiento del establecimiento, a la seguridad o a la actividad de los trabajadores, o

5 El Código del Trabajo de 1931 desarrolló más minuciosamente la causal, sancionando el "perjuicio material causado intencionalmente en las máquinas, herramientas, útiles de trabajo, productos o mercaderías”. La Ley N 16.455 (de 1966) también mantuvo en términos generales el texto de la causal, aun cuando corrigió y complementó parte de su redacción: en vez de hablar de "máquinas" utilizó la expresión "maquinarias"; y le agregó un nuevo objeto de perjuicio ahora en relación con las "instalaciones". De esta forma, la Ley $\mathrm{N}^{\circ} 16.455 \mathrm{am}$ plió las hipótesis legales de infracción en lo que respecta a esta causal. Con todo, el sabotaje propiamente dicho también fue sancionado por el artículo $634 \mathrm{~N}^{\circ} 3$ y $487 \mathrm{~N}^{\circ} 4$ del Código del Trabajo de 1931. Pero en este último caso, lo que hacía el Código era establecer un catálogo de figuras delictivas contrarias a la libertad de trabajo, y entre las cuales el sabotaje era explicado como la destrucción de materias, instrumentos o productos del trabajo o mercaderías [por todos Soto Calderón (1961) 121].

6 Por todos Walker Errázuriz, Francisco (1990), Terminación del contrato de trabajo. Santiago: Cepet, 302 pp., p. 52.

Como señaló el Mensaje Presidencial que dio origen a la Ley N 19010, el proyecto "propone derogar el artículo 157 del Código del Trabajo porque la mayoría de las situaciones que contempla no se refieren al marco de las relaciones laborales en la empresa". 
a la salud de estos"; y el "perjuicio material causado intencionalmente en las instalaciones, maquinarias, herramientas, útiles de trabajo, productos o mercaderías". Ambas figuras fueron posteriormente recogidas en el vigente Código del Trabajo, aun cuando habrá que reconocer que su actual estructura se encuentra más vinculada a cuestiones de orden netamente contractual. Desde esta perspectiva, y en el caso del artículo $160 \mathrm{~N}^{\circ} 6$ CT, el Código busca sancionar no solo alternativas propias de sabotaje sino que, también, la ejecución de actos dañosos que perjudiquen el patrimonio del empleador.

Normas de esta naturaleza no son usuales en el Derecho comparado. A diferencia de lo que ocurre con otros ordenamientos, que se limitan a establecer una causa única y genérica de incumplimiento, el Código chileno opta por un catálogo más o menos detallado y en el cual incorpora infracciones de gravedad relativamente aceptadas. Este sistema de causas específicas se justifica en atención al principio de seguridad jurídica, y permite que el trabajador tenga la garantía que solo podrá ser despedido en razón de situaciones concretas que el legislador ha regulado. Con todo, en el entorno latinoamericano, existen algunas legislaciones comparadas que han sancionado la ejecución de actos dańosos como fundamento de extinción del contrato. Ese es el caso, por ejemplo, del artículo 47 fracción V de la Ley Federal del Trabajo de México, de 1970, el cual sanciona todo acto que suponga "ocasionar el trabajador, intencionalmente, perjuicios materiales durante el desempeño de las labores o con motivo de ellas, en los edificios, obras, maquinaria, instrumentos, materias primas y demás objetos relacionados con el trabajo" 8 . Un planteamiento similar se encuentra en el artículo 62 del Código Sustantivo del Trabajo de Colombia de 1950 (actualmente vigente), y 79, letra g), de la Ley Orgánica del Trabajo, los Trabajadores y las Trabajadoras, de Venezuela (de 2012). El primero de los preceptos citados señala que son justas causas para dar por terminado unilateralmente el contrato de trabajo por parte del empleador: "4. Todo daño material causado intencionalmente a los edificios, obras, maquinarias y materias primas, instrumentos y demás objetos relacionados con el trabajo, y toda grave negligencia que ponga en peligro la seguridad de las personas o de las cosas". La legislación venezolana, por su parte, indica que será causa justificada de despido el "perjuicio material causado intencionalmente o con negligencia grave en las máquinas, herramientas y útiles de trabajo, mobiliario de la entidad de trabajo, materias primas o productos elaborados o en elaboración, plantaciones y otras pertenencias".

Dentro del contexto temático que hemos formulado, la hipótesis extintiva del artículo $160 \mathrm{~N}^{\circ} 6 \mathrm{CT}$ presenta una serie de interrogantes que

\footnotetext{
8 Sobre el particular, De Buen Lozano, Néstor (1992), Derecho del Trabajo, T. II, 9a edición. México: Porrúa, 890 pp., p. 95.
} 
no han encontrado adecuada respuesta ni en la doctrina ni en la jurisprudencia. Una de esas interrogantes se vincula con la extensión de la causal. Ya se ha dicho que los manuales y las escasas sentencias que hay sobre el tema se han limitado a vincular esta norma con los supuestos clásicos de sabotaje. Sin embargo, no existe claridad en torno a si esta causal resulta o no aplicable a otro tipo de actos dańosos que abarquen incluso los atentados al valor de uso de un bien o a su inutilización. Tampoco existe demasiado consenso en cuanto a si se trata de una simple figura penal o, por el contrario, la tesis que subyace en el Código es más amplia y compleja que la mera existencia de un delito. Ciertamente, la norma en comento adolece en varios aspectos de vaguedad extensional y tiene evidentes dificultades para determinar sus contornos.

La gravedad es otro de los temas pendientes dentro de la causal. Sabemos que esta cualidad se encuentra repartida dentro del artículo 160 CT, pero hasta ahora no existen mayores noticias sobre la manera en que la gravedad se incorpora en esta específica hipótesis extintiva. Similares reflexiones podrían formularse en relación con los bienes que pueden ser objeto de protección legal: ¡la enumeración que el Código hace de los bienes que se encuentran resguardados es taxativa, o por el contrario tiene una vocación meramente ejemplar abriendo su aplicación a cualquier tipo de bien (material o inmaterial) del empleador? Por último, tampoco hay certeza en lo que respecta a si la figura solo regula las infracciones de resultado o también las de peligro.

Todas las interrogantes anteriores se intentan responder en el presente estudio. Ante el silencio dogmático y jurisprudencial, la sola formulación de estas dudas ya constituye una novedad (así como las incipientes respuestas a las mismas), y permite avanzar en la estandarización de criterios capaces de resolver cuáles son los efectos extintivos que se derivan de la ejecución de actos dañosos.

\section{II) EL CONTENIDO DE LA CAUSAL}

\section{1) BIEN JURÍDICO PROTEGIDO}

En las causas de despido disciplinario pervive una fundamentación genérica vinculada a la disciplina de la actividad laboral. Las relaciones de trabajo dejan en evidencia una jerarquía funcional y organizativa que obliga a respetar normas mínimas de comportamiento. A lo anterior podría agregarse que por la celebración del contrato de trabajo, el trabajador asume el deber inicial de cumplir sus obligaciones de forma diligente? ${ }^{9}$. La diligencia

9 Corte Suprema. 31 de marzo de 2004. Rol N 1053-2003. Recurso de Casación en el Fondo. Caratulado "Fuentes Pezoa con Ecokorp Ltda.". GJ No 286 (2004), p. 293. 
implica, entre otras cosas, la necesidad de abstenerse de acciones que perjudiquen la adecuada ejecución de las actividades. Y desde esta perspectiva, no sería diligente un trabajador que perturba y evita que el resto de los trabajadores desarrolle normalmente sus obligaciones.

No obstante, en el caso de la causal del artículo $160 \mathrm{~N}^{\circ} 6 \mathrm{CT}$ existen a lo menos dos elementos adicionales que permiten justificar la aplicación de la hipótesis extintiva. En primer lugar, la figura descrita por el Código busca proteger el patrimonio del empleador en el entendido que determinados bienes que él utiliza en la actividad productiva se ven afectados tanto en su integridad o consistencia material, como en el valor de uso del mismo. El empleador, en tanto titular de los bienes, tiene derecho a la existencia o permanencia incólume de sus bienes, razón por la cual cualquier atentado debe ser considerado como una infracción de orden disciplinar. En esta misma línea, la acción reprochada afecta la valoración económica del bien y en definitiva perjudica la actividad productiva que ha puesto en movimiento la contraparte en el vínculo laboral. No hay que olvidar que los actos a que se refiere la causal traen aparejado un empobrecimiento del empleador (ya sea por una alteración del bien o por una pérdida de su valor de uso), cuestión que grafica el daño o perjuicio. Ese es en definitiva, el bien jurídico protegido: el patrimonio que el empleador ha utilizado para poner en movimiento la actividad productiva. En este orden de ideas, si el bien afectado carece de valor económico o de utilidad productiva, o lisa y llanamente no se ha producido un perjuicio de esta índole, entonces difícilmente podría verificarse esta específica causal de despido (v. gr., los dańos en contra de bienes de mero valor afectivo del empleador, tales como una foto familiar o un galvano de reconocimiento). A este respecto, no hay que olvidar que la norma del artículo $160 \mathrm{~N}^{\circ} 6 \mathrm{CT}$ pone el acento en bienes con utilidad productiva y no en cualquier bien de la empresa. Por cierto, en caso de producirse daños a bienes del empleador que carecen de valor económico o de utilidad productiva, dicha conducta puede dar lugar a otro tipo de causales de extinción como sería el caso de incumplimiento grave de las obligaciones o la falta de probidad.

Por otra parte, y muy unido a lo anterior, la causal busca proteger la utilidad que el bien tiene para el fin al que estaba destinado. La inutilización o alteración de instalaciones, maquinarias u otros títulos de trabajo implica que el bien pierde sus cualidades esenciales para el cual era utilizado, y eso ciertamente que termina afectando el funcionamiento general de la actividad que el titular había puesto en movimiento. Desde esta perspectiva, el empleador pierde un atributo propio de la ajenidad ya que no puede aprovecharse de los frutos derivados del uso productivo de los bienes alterados o inutilizados ${ }^{10}$.

10 Esta ajenidad implica que el resultado o los frutos del trabajo sean atribuidos inicial y directamente al empleador. Y más aún, la referencia a los frutos se conecta con la utilidad 


\section{2) EL SUJETO ACTIVO Y PASIVO}

La redacción que utiliza el artículo $160 \mathrm{~N}^{\circ} 6$ CT no deja mayor lugar a dudas, en el sentido que el autor de la infracción es el trabajador dependiente. Su participación en el perjuicio es, en principio, directa. Lo anterior pone el énfasis en la acción ejecutada por el trabajador y no tanto en un "no hacer", aun cuando esta pasividad u omisión provoquen un resultado prohibido.

Como es fácilmente advertible, los niveles de autoría pueden ser disímiles. Desde luego, el trabajador será responsable del perjuicio cuando ha ejecutado directa y personalmente la acción que genera el daño, y sin valerse de intermediarios. También tendrá el carácter de sujeto activo, cuando ha tenido una aportación decisiva en el resultado perjudicial. Ello ocurriría, por ejemplo, si el trabajador advierte la ocurrencia del hecho dañoso en el cual no participó inicialmente, pero realiza una acción decidida para evitar que otros impidan el resultado prohibido (v. gr., un incendio en el cual se impide la llegada del cuerpo de bomberos). Lo mismo ocurriría en el caso de que el trabajador se apostara en un lugar cercano a aquel en el que se produce la acción perjudicial, a objeto de avisar la presencia del empleador o de la fuerza pública. Esta condición de cooperador inmediato que eventualmente puede ostentar el trabajador, deja al descubierto una acción inmediata para que otras personas puedan ejecutar con seguridad el acto que trae como consecuencia el perjuicio.

La condición de sujeto activo se presenta, además, en aquellos supuestos en que el trabajador participa en calidad de autor intelectual, coautor, forzador o instigador del acto que deviene en perjuicio ${ }^{11}$. En todas estas hipótesis, el trabajador tiene un rol participativo relevante en la producción del perjuicio, cuestión que deja en evidencia su condición de sujeto activo. Distinto sería el caso, por cierto, del trabajador que encubre: él quedaría fuera de la hipótesis de sujeto activo de la causal, ya que por definición el encubridor solo actúa cuando la infracción se encuentra terminada.

El sujeto pasivo, por su parte, es indudablemente el empleador (ya sea persona natural o jurídica). La redacción ocupada por el Código se

patrimonial de los bienes del trabajo, en el entendido que la utilidad patrimonial se traspasa, en virtud del contrato de trabajo, a una persona distinta de aquel que ejecuta la actividad, permitiendo la apropiación del trabajo ajeno [Alarcón Caracuel, Manuel Ramón (1986), "La ajenidad en el mercado: un criterio definitorio del contrato de trabajo". REDT No 28, Madrid, 1986, 495-544 pp., pp. 495 y siguientes]. Si los bienes dañados o alterados por el trabajador impiden que el empleador pueda aprovecharse de los frutos de la actividad resultante de esos bienes, entonces ciertamente existe un perjuicio que, de paso, afecta la ajenidad.

11 Gómez Abelleira, Francisco Javier (2009), "Las causas disciplinarias del despido", 2a edición. En Sempere Navarro, Antonio-Vicente (director): El despido. Pamplona: AranzadiThomson Reuters, pp. 146-315, p. 240. 
encuentra íntimamente vinculada a bienes de titularidad del empleador; por tanto, el sujeto pasivo será precisamente dicho titular. Como es sabido, la condición de empleador permite concluir que este ostenta una titularidad laboral sobre las instalaciones, maquinarias, herramientas, útiles de trabajo, mercaderías o productos que se utilizan o que derivan de la actividad productiva. La condición de titular puede surgir tanto de una titularidad básica o independiente (como sería el dominio), así como de cualquier otro derecho que reconozca su condición. Por tanto, la titularidad resulta predicable con respecto al derecho que tienen sujetos tan disimiles como el poseedor, el arrendatario, el usufructuario o incluso el prestatario, sin que el vínculo de propiedad sobre los bienes sea la nota distintiva sobre la cual se construye el artículo $160 \mathrm{~N}^{\circ} 6 \mathrm{CT}^{12}$. Lo que se exige, en definitiva, es que el empleador tenga una determinada capacidad o poder de decisión sobre el bien y cuya alteración o destrucción lo perjudica ${ }^{13}$. Desde esta perspectiva, el empleador adquiere la condición de sujeto pasivo pues para estos efectos se trata de un perjudicado con el acto sancionado toda vez que tiene la calidad de titular de un interés específico que se ve alterado ${ }^{14}$.

Excepcionalmente, el empleador puede mantener la condición de sujeto pasivo cuando el trabajador de la empresa principal destruye o altera bienes del subcontratista que se utilizan en la actividad productiva. Si los dańos provocados a los bienes del subcontratista tienen por objeto perjudicar a la empresa principal, entonces legítimamente el empleador podría reclamar un interés específico que le permitiría aplicar la causal.

En otro orden de ideas, los atentados que se provoquen en bienes propios del trabajador, o de otros compañeros de labores, deben quedar excluidos de esta específica causa legal. Por el contrario, los daños provocados a los bienes propios del empleador, y que se encuentran bajo el cuidado y conservación del trabajador para el desarrollo de la actividad laboral, ciertamente que caben dentro de la hipótesis extintiva ${ }^{15}$. Lo anterior

12 Siguiendo a la doctrina penal, pero aplicable al ámbito laboral, no cabrían dentro de la calidad de bienes perjudicados ni las rei nullius ni las rei derelictae [Andrés Domínguez, Ana Cristina (2011), "Los daños". En F. Javier Álvarez García (director): Derecho Penal español. Parte Especial, T. II. Valencia: Tirant lo Blanch, pp. 417-443, p. 420]. Véase también el ejemplo propuesto para el ámbito penal por Corcoy Bidasolo, Mirentxu (1990), "La protección penal del sabotaje informático. Especial consideración de los delitos de daños". La Ley (1990), T. I, pp. 1000-1016, p. 1014: "En el ámbito de la informática la específica configuración de los contratos de servicios determina que en muchos casos el sujeto solo tenga un derecho de disposición sobre el programa, mientras que la propiedad la sustenta la empresa de servicios".

13 Miñambres Puig, César (1985), El Centro de Trabajo. Madrid: Servicio de Publicaciones Ministerio de Trabajo y Seguridad Social, 251 pp., p. 136.

14 En esta línea, Walker Errázuriz (1990) 61: "Como la ley no distingue el perjuicio, no se circunscribe solo a los bienes de la empresa misma, sino que puede tratarse de bienes que, perteneciendo a terceros, el trabajador los tenga a su cargo por razones de su trabajo".

15 Aguilera Izquierdo, Raquel (1997), Las causas del despido disciplinario y su valoración por la jurisprudencia. Pamplona: Aranzadi, 323 pp., p. 61. 
no impide que también resulten sancionables aquellos perjuicios causados intencionalmente en contra de bienes de compañeros de labores o de terceros vinculados al empleador (v. gr., clientes o proveedores) ${ }^{16}$, pero en estos casos la causal tendría que ser otra más vinculada al incumplimiento grave o a la falta de probidad (art. $160 \mathrm{~N}^{\circ} 1$ ó 7 CT), sobre todo si los perjuicios dolosamente causados por el dependiente pueden eventualmente generar algún grado de responsabilidad posterior en el empleador ${ }^{17}$.

\section{3) EL ÁMBITO DE EJECUCIÓN DE LA INFRACCIÓN: CON OCASIÓN DEL TRABAJO}

El contexto en el cual se desenvuelven las causas disciplinarias, es esencialmente contractual. Cualquier conducta que rebase dicho marco no debiera, en principio, ser objeto del poder disciplinario del empleador. La conclusión anterior también resulta predicable a la conducta sancionada por el artículo $160 \mathrm{~N}^{\circ} 6 \mathrm{CT}$, toda vez que la acción u omisión destinada a perjudicar debe producirse irremediablemente con ocasión del contrato de trabajo.

La referencia legal a instalaciones, maquinarias, herramientas, útiles de trabajo, productos o mercaderías ratifica lo que se viene diciendo. Se trata de bienes íntimamente relacionados con la actividad productiva y, en definitiva, con el ámbito del contrato de trabajo. Más aún, se vincula con bienes necesarios para que el trabajo del dependiente o la actividad productiva en general puedan desplegarse.

El ámbito laboral de la infracción no necesariamente implica que el daño deba producirse de forma exclusiva en el lugar de trabajo. Tampoco exige que el inicio de la acción, o los actos preparatorios, estén vinculados al ámbito locativo o geográfico donde se desempeñan las funciones. Lo que se exige, más bien, es que la infracción se lleve a cabo con ocasión del trabajo (más allá del lugar concreto en que esta se ha verificado). Por cierto, la mayor parte de las veces las infracciones se ejecutarán en el mismo lugar donde se prestan los servicios; pero dada la amplitud de alternativas que señala el artículo 160 Nº CT, nada impide que los dańos o alteraciones se produzcan fuera del establecimiento. Tan evidente

16 Gómez Abelleira, (2009) 278.

17 Ese sería el caso, por ejemplo, de aquellos supuestos en que se le ha encargado al empleador transportar, custodiar o gestionar bienes de terceros y en que el agente directo del dańo había sido encomendado por dicho empleador para efectuar labores de guarda o custodia [Zelaya Etchegaray, Pedro (1995), La responsabilidad civil del empresario por los daños causados por su dependiente. Pamplona: Aranzadi, 695 pp., p. 541]. A mayor abundamiento, véase el artículo $156 \mathrm{~N}^{\circ} 3$ del Código Aeronáutico el cual señala que el explotador de la aeronave no responderá por daños a terceros en la superficie "3.- si son causados por un acto de sabotaje". 
es lo anterior, que en los casos de sabotaje informático el daño efectivo se produce en un ámbito muchas veces ajeno a espacios físicos de la empresa. Más aun, daños o alteraciones de productos o mercaderías se pueden producir en el transporte llevado a cabo por una empresa externa o incluso fuera del ámbito de supervigilancia, directa o indirecta, del empleador. Ese sería el caso, por ejemplo, que se produce al envenenar productos alimenticios dispuestos para la venta en un local sobre el cual el empleador ni siquiera tiene titularidad, o bien cuando existen actos de sabotaje en la vía pública.

En consecuencia, y dada la amplitud de alternativas que plantea el Código, lo relevante es que la conducta prohibida se ejecute con ocasión del trabajo, independientemente de si el acto en cuestión se ha iniciado en el específico lugar donde se ejecutan las tareas propias del contrato.

\section{4) EL NÚCLEO DE LA INFRACCIÓN: EL PERJUICIO}

El artículo $160 \mathrm{~N}^{\circ} 6 \mathrm{CT}$ sanciona en términos genéricos el perjuicio material ${ }^{18}$, y cuyo origen se encuentra precisamente en la calidad de agente provocador que eventualmente puede ostentar el trabajador. De alguna forma, el Código pone el acento no tanto en el riesgo sino que en la existencia de un resultado perjudicial, cuestión que permite superar conceptualmente las figuras de mero sabotaje. Desde esta perspectiva, se trata de una conducta que ejecuta dolosamente el trabajador y que lesiona los intereses del empleador. Dicho interés se ve reflejado principalmente en el patrimonio que él tiene para poner en movimiento la actividad productiva y que se ve afectado por el actuar el trabajador (cuestión que desde luego debe ser comprobada ${ }^{19}$. La concurrencia de un perjuicio deja al descubierto un empobrecimiento derivado de actos de destrucción, alteración o deterioro; y en caso alguno puede pretenderse que este perjuicio quede amparado por la lógica de ajenidad del trabajo, pues ello implicaría reconocerle al transgresor una inmunidad absoluta ${ }^{20}$.

18 Expresión poco afortunada, a juicio de De Buen Lozano (1992) p. 95 (quien analiza una norma de similar redacción en la Ley Federal del Trabajo de México), "ya que es evidente que la intención es referirse a los daños, que son pérdidas o menoscabos sufridos en un patrimonio y no a los perjuicios, que denotan ganancias lícitas que se dejan de percibir”.

19 Sentencia de la Corte Suprema. 21 de junio de 2001. Rol N² 2081-2001. Recurso de Casación en el Fondo. Caratulado "Tapia Saavedra con Empresa de Buses”. GJ N² 252 (2001), p. 173.

20 Agra Viforcos, Beatriz (2010), "Obligaciones indemnizatorias del trabajador a su empresario. Supuestos de hecho a la luz de los pronunciamientos judiciales”. AL N ${ }^{\circ}$ 2, pp. 1-24, p. 1. También Cremades, Bernardo María (1969), La sanción disciplinaria en la empresa. Madrid: Instituto de Estudios Políticos, 312 pp., p. 168. 


\section{1) LA IDEA DE PERJUICIO}

El Código del Trabajo centra el ilícito en la existencia de un perjuicio. Pero esa pura referencia resulta ambigua, dando origen a varios sentidos posibles en relación con el daño que se exige. Una primera alternativa es reducir la idea de perjuicio a un mero daño material reflejado en la destrucción de la cosa, en su deterioro o en su menoscabo estructural. Habría en esta tesis un énfasis en el ataque a la integridad material del bien que afecta su existencia o permanencia incólume. De esta manera, y fundado en una teoría material, el perjuicio se configuraría como todo deterioro, menoscabo o alteración de una cosa relevante del empleador y que tenga por consecuencia su inutilización total o parcial ${ }^{21}$.

Con todo, un criterio meramente material resulta reduccionista y termina dejando fuera del diseño causal una serie de figuras que ciertamente pueden perjudicar al empleador. Lo anterior obliga a revisar los casos de perjuicio desde una perspectiva funcional (Funktionsvereitelungstheorie), la cual vincula el daño con la pérdida en el valor de uso o bien con la inutilización del objeto (sin que exista necesariamente un deterioro o menoscabo material) ${ }^{22}$.

En este orden de ideas, el bien afectado pierde sus cualidades y utilidades intrínsecas, demostrando ineficacia productiva o falta de rentabili$\mathrm{dad}^{23}$. Lo expuesto no implica que el perjuicio traiga como consecuencia la ruina del perjudicado, o que la pérdida sea especialmente significativa; simplemente, se sanciona el hecho de que el bien afectado pierda su valor de uso. De esta forma, el perjuicio sería de tal magnitud que terminaría convirtiendo al bien del empleador en algo inservible para el fin a que

21 Véase la configuración que se le otorga al daño, en materia penal, en ETCHEBERRY, Alfredo (1976), Derecho Penal, T. III, 2a edición. Santiago: Editora Nacional Gabriela Mistral, 490 pp., p. 368. En el ámbito comparado, véase además Andrés Domínguez (2011) 419. En el plano jurisprudencial, sentencia de la Corte Suprema. 5 de enero de 1998. Rol No 4571 96. Recurso de Casación en el Fondo. Caratulado "Viveres Sánchez con Deves Rojas y Cía. Limitada". RDJ T. XCV, sección tercera (1998), p. 1.

22 En esa línea, por ejemplo, sentencia de la Corte de Apelaciones de Santiago. 9 de octubre de 2008. Rol No 6854-2007. Recurso de Apelación deducido por Redbus S.A. Disponible en www.poderjudicial.cl: "Cuarto: Que, de acuerdo a lo anterior, resulta evidente el daño generado al servicio que la demandada se obligó a prestar, es decir, el perjuicio material, en este caso, está dado por la paralización de los buses de la empresa, actividad propia de su giro".

23 Corcoy Bidasolo, Mirentxu (2011), "Los daños". En Corcoy, Mirentxu, y Mir, Santiago (directores): Comentarios al Código Penal. Valencia: Tirant lo Blanch, Valencia, 584-594 pp., p. 585. En igual sentido, Corcoy Bidasolo (1990) 1014: "En consecuencia, la transformación de la sustancia de la cosa será daño, habrá daño si la cosa no funciona correctamente o si se disminuyen sus posibilidades de aplicación o eficacia”. Cabe tener presente que el Código del Trabajo de 1987, admitía expresamente la teoría funcional al sancionar "la comisión de actos (... que) disminuyan su valor o causen su deterioro". Si bien es cierto que la Ley $\mathrm{N}^{\circ}$ 19.010 utilizó otra redacción, a nuestro entender ello no implica que se haya eliminado la aplicación de la causal para aquellos actos en que se afecta el valor de uso del bien. 
está destinado. Es decir, el bien no podría cumplir la finalidad para la cual lo destina el empleador, generando de esa manera un perjuicio no solo en el bien propiamente tal sino que, además, en el uso habitual que el empleador le otorgaba a este.

Una adecuada comprensión de la causal obliga a concluir que su alcance se refiere tanto a la destrucción del bien así como a la pérdida de su valor de uso $^{24}$. La postura que planteamos constituye una clara diferencia con la regulación que sobre esta materia existe en el Derecho Penal ${ }^{25}$, pero se explica en atención a que el ordenamiento laboral establece una regulación más amplia del ilícito incorporando -dentro de la infracciónno solo el quebranto físico del objeto sino que además los ataques al valor de uso del bien (independientemente del hecho de que la lesión afecte o no la sustancia). En esta última hipótesis quedarían los actos consistentes en la liberación de animales, la apertura de un grifo a objeto de dejar escapar el agua, la paralización de vehículos o la acción consistente en desinflar las ruedas de un automóvil utilizado en la actividad productiva y que trae como consecuencia un perjuicio para el empleador, entre otras varias alternativas ${ }^{26}$.

La destrucción o menoscabo material es fácilmente identificable, pues los elementos estructurales o substanciales del bien se ven afectados. Ello ocurriría en casos de destrucción, aniquilamiento o inutilización del objeto. No obstante, la pérdida de valor de uso de la cosa amplia las alternativas. Así, por ejemplo, la conducta prohibida incorporaría supuestos tales como la infección o contagio de ganado, el entorpecimiento de la red de abastecimiento de agua para el funcionamiento de la actividad productiva, las dificultades que se imponen sobre las redes inalámbricas, conductas todas que si bien no alterar la substancia material del bien sí impiden aprovechar su uso.

Desde esta perspectiva, y a nuestro entender, el perjuicio material se produce tanto con la destrucción o alteración de la cosa como por su lesión del valor de uso, ocultación o desaparición. En el primer caso, los

24 CAP De SAntiago, Rol N D-977-84-T, p. 168: “Que la causal invocada (...) requiere que por acción dolosa o mal intencionada del exonerado resulten la destrucción de materiales, instrumentos o productos de trabajo o mercaderías, o se disminuya o menoscabe su valor en razón del deterioro o dańo que se les causa”.

25 Andrés Domínguez (2011) 422.

26 En la jurisprudencia nacional existe una situación de hecho que grafica la pertinencia de la causal en el evento de producirse un ataque al valor de uso del bien. Se trata del caso de un trabajador que, junto a otros, bloquea la salida de los buses del terminal de una empresa de transportes desde las 06.00 a las 10.00 horas. Para asegurar la acción, retiraron las llaves de las máquinas impidiendo prestar el servicio de transporte a que se había obligado la empresa. La sentencia respectiva concluyó que en este caso resultaba plenamente aplicable la causal del artículo $160 \mathrm{~N}^{\circ} 6 \mathrm{CT}$, ya que "el perjuicio material, en este caso, está dado por la paralización de los buses de la empresa, actividad propia de su giro”. Sobre el particular, véase la sentencia de la CAP de Santiago, Rol N 6854-2007. 
bienes del empleador son destruidos cuando deja de existir en la substancia y forma que tenía; provocando de paso una inutilización de un bien relevante para el empleador, dejándolo inepto para el fin a que estaba destinado. En el segundo caso, la ocultación o desaparición permanente del bien impide que el empleador pueda utilizar de forma regular los útiles, instalaciones o maquinarias.

Las referencias anteriores obligan a dejar fuera del núcleo infraccional a una serie de figuras que ciertamente causan perjuicio al empleador, pero que no encuadran con el diseño de la causal. Así ocurriría, por ejemplo, cuando el trabajador utiliza en beneficio propio ciertos bienes o utensilios del empleador, o bien cuando se sustraen temporalmente herramientas o maquinarias de la empresa para provecho de terceros conocidos del trabajador. No cabe duda que en estos casos sí se produce un perjuicio para el empleador, pero ello se encuentra más vinculado a infracciones propias de la buena fe contractual (tales como el incumplimiento grave de las obligaciones o la falta de probidad), que a la figura del artículo $160 \mathrm{~N}^{\circ} 6 \mathrm{CT}$.

\section{2) LA EXIGENCIA DE QUE El PERJUICIO SEA MATERIAL}

El Código exige que el perjuicio sea material. Es decir, debe tratarse de un detrimento concreto sobre la cosa y desde luego que provoque la disminución real y efectiva del patrimonio del empleador. En el fondo, la causal presupone una conducta del trabajador que altera, destruye o inutiliza el bien del titular de la actividad productiva. Lo anterior no impide, al menos desde una óptica teórica, que la infracción esté fundada en una omisión del trabajador. Ello ocurriría, por ejemplo, en todos aquellos casos en que el trabajador se encuentre en una posición de garante en relación con el empleador y se inhibe de realizar una conducta que evite el perjuicio.

La condición de garante no es lo mismo que estar simplemente en condiciones objetivas de evitar o impedir un perjuicio: en el primer caso, el garante tiene el deber jurídico concreto de actuar para impedir que se ejecute la acción perjudicial; en el segundo caso, el trabajador se encontraría en una mera situación de hecho. En materia laboral, la idea de garante es algo más amplia que aquella que se utiliza en el ámbito penal, aun cuando subyace la dificultad en orden a determinar si el trabajador se encuentra obligado a evitar un perjuicio en cuyo origen no ha participado $^{27}$. Una primera interpretación, discurre sobre la base que por la celebración del contrato de trabajo, el trabajador asume un deber inicial

27 Un análisis de las diversas posiciones doctrinales relativas a la idea penal de garante, puede consultarse en Izquierdo Orrego, Cristóbal (2006), "Comisión por omisión. Algunas consideraciones sobre la injerencia como fuente de la posición de garante”. RCHD Vol. 33 $\mathrm{N}^{\circ} 2$, pp. 329-343, pp. 333 y ss. 
de diligencia que entre otras cosas le obliga a ejecutar aquellas medidas conservativas destinadas a evitar perjuicios a su contraparte. El contrato sería la fuente de su obligación y, por tanto, tendría el deber de realizar aquellos actos positivos que racionalmente pueden evitar el perjuicio. Desde esta perspectiva, la omisión dolosa del trabajador sería sancionable mediante la causal del artículo $160 \mathrm{~N}^{\circ} 6$ CT. Otra tesis, sin embargo, discurre sobre la base que la infracción del deber de diligencia solo es sancionable por la causal del artículo $160 \mathrm{~N}^{\circ} 7 \mathrm{CT}$ (incumplimiento grave de las obligaciones que impone el contrato). A nuestro entender, los particulares requisitos de la primera de las causales mencionadas, exigirían una interpretación restrictiva del concepto de garante, sin perjuicio que la omisión pueda encuadrarse como una típica infracción a la buena fe contractual. La diferencia no es menor, ya que los supuestos de omisión solo podrían ser sancionados en la hipótesis que el trabajador tuviese el deber de intervenir en calidad de garante (v. gr., el guardia de seguridad que se inhibe de realizar actos destinados a evitar el robo de especies de la empresa). Si se concluyera que la causal del artículo $160 \mathrm{~N}^{\circ} 6 \mathrm{CT}$ solo es aplicable a los casos en que el trabajador ostente la condición de garante, entonces la abstención de prestar apoyo para evitar perjuicios (estando, por cierto en condiciones de resistir la conducta perjudicial de un tercero), solo podría ser sancionada por la causal del artículo $160 \mathrm{~N}^{\circ} 7 \mathrm{CT}$. Con todo, en la práctica, y sin optar expresamente por una u otra noción de garante, la jurisprudencia laboral ha utilizado la causal del artículo 160 $\mathrm{N}^{\circ} 6$ CT para sancionar acciones determinadas; solo por excepción, la jurisprudencia ha sancionado también la omisión del trabajador ${ }^{28}$.

En otro orden de ideas, también es posible plantear interrogantes en lo que respecta a los actos de tentativa. Ello ocurriría, por ejemplo, cuando el trabajador principia su actividad destinada a la destrucción o deterioro del bien (sin provocar perjuicio concreto) y es inmovilizado por otra persona a objeto de evitar la ejecución del ilícito ${ }^{29}$. Igual calificación jurídica ocurriría en los casos de sabotaje informático en que el trabajador introduce un virus que resulta inefectivo. La actual redacción del Código es taxativa y parece no dejar dudas a este respecto: lo que se sanciona es el perjuicio material. Dicho perjuicio implica una infracción de resultado (no de mera actividad), razón por la cual si el trabajador ha iniciado una acción tendiente a perjudicar, y en definitiva no logra consumarla,

28 Sentencia de la CAP de SAntiago, Rol N 6854-2007, la cual considera que la causal del artículo $160 \mathrm{~N}^{\circ} 6 \mathrm{CT}$ "requiere una acción u omisión dolosa o mal intencionada".

29 Distinto sería el caso, por cierto, en que el trabajador inicia la actividad perjudicial deteriorando parcialmente el bien de la empresa (para luego ser neutralizado en su acción). Aun cuando en esta hipótesis el perjuicio es menor probablemente al que deseaba el autor del acto, de todas formas se verifica la existencia de un perjuicio material. Lo que habría que calificar, con todo, es si dicho perjuicio reúne la entidad suficiente para aplicar la causal del artículo $160 \mathrm{~N}^{\circ} 6 \mathrm{CT}$. 
entonces dicha conducta no es sancionable por el artículo $160 \mathrm{~N}^{\circ} 6 \mathrm{CT}$ (sin perjuicio de aplicar, en la especie, la norma del artículo $160 \mathrm{~N}^{\circ} 1$ ó 7 CT). Lo que predomina en esta conclusión es la tesis de que en la tentativa no hay resultado de perjuicio, cuestión que la aparta decididamente de la redacción utilizada en el artículo $160 \mathrm{~N}^{\circ} 6 \mathrm{CT}$.

Adicionalmente, la referencia legal parece dejar fuera los detrimentos meramente inmateriales o aquellos que solo provoquen daño afectivo o moral $^{30}$. Desde esta perspectiva, los dańos que se provoquen a la reputación o prestigio del empleador no pueden quedar cubiertos por esta específica causa disciplinaria, así como tampoco aquellos que no se manifiestan de manera coetánea a la conducta del trabajador (v. gr., los actos que perjudican la relación futura del empleador con su clientela).

Con todo, de lo que no cabe duda es que el perjuicio debe ser de una entidad relevante y sobre un bien que tenga una importancia necesaria para el buen desempeño de la actividad productiva ${ }^{31}$. Esa es la única manera de concluir que la infracción es realmente grave y de una entidad objetiva suficiente ${ }^{32}$. Desde esta perspectiva, un perjuicio irrelevante, o de fácil solución, quedaría fuera de la hipótesis legal. Ello exige distinguir aquellos actos que producen - eventual o efectivamente- un daño determinado, y que ostentan una mínima concreción, de aquellas actuaciones irrelevantes e incapaces de afectar los bienes del empleador. Por cierto, la gravedad no tiene que emanar de una pluralidad de actos dañosos, ya que una sola conducta lesiva puede revestir la exigencia de gravedad. No obstante, es preciso aclarar que la gravedad del perjuicio no se mide exclusivamente por el monto económico del detrimento, sino que también por el quebrantamiento irrestaurable del vínculo de confianza ${ }^{33}$. Lo anterior obliga a calificar la entidad del perjuicio en base a una serie de criterios (no solo el de carácter económico), y entre los cuales serán relevantes la antigüedad en el empleo, el cargo o función del trabajador, y la incrustación del bien deteriorado dentro del ciclo productivo (más allá de la necesaria importancia a la cual se ha hecho referencia).

\footnotetext{
30 Una tesis contraria ha sido planteada por la doctrina comparada, en el sentido que la extinción también debiera proceder en casos de infracción a los intereses morales del empleador. Sobre el particular, puede consultarse Cabanellas, Guillermo (1988), Tratado de Derecho del Trabajo, T. II, Vol. 3, 3a edición. Buenos Aires: Heliasta, 539 pp., p. 194.

31 Sentencia de la CAP de Antofagasta, Rol N 145-2011: “(...) un daño aislado producto de una ofuscación en una camioneta, no constituye la gravedad que exige la norma”.

32 Cabanellas (1988) 195. Sería dudosa la ocurrencia de la causal, en aquellos casos en que el daño provocado generara beneficio al empleador. Ello sucedería, por ejemplo, si el trabajador mata a un animal del empleador cuyo mantenimiento solo produce gastos. Lo que ocurre es que si la cosa destruida o inutilizada no es valorable económicamente y tampoco es susceptible de deterioro, entonces técnicamente no existe perjuicio por parte del trabajador. Por cierto, un hecho como el que se describe podría dar lugar a otro tipo de causales.

33 Aguilera Izquierdo (1997) 64. En similar sentido, Gómez Abelleira (2009) 278.
} 


\section{5) LA INTENCIONALIDAD DE LA ACCIÓN REPROCHADA}

En el ámbito laboral, toda conducta infraccional no solo debe ser imputable al trabajador sino que, además, debe ser ejecutada voluntariamente por este ${ }^{34}$. Salvo excepciones, la voluntariedad no supone la concurrencia de un dolo específico en la ejecución de la conducta ya que la regla general en materia de despido disciplinario es que la acción reprochada no se haya ejecutado con un especial ánimo de provocación del ilícito. Por ejemplo, la circunstancia de faltar dos días seguidos, sin causa justificada, de por sí genera responsabilidad laboral, más allá de la intención que animó el comportamiento del trabajador ${ }^{35}$.

Llegados a este estadio, nos enfrentamos a una nueva ambigüedad del texto legal: ¿basta la voluntariedad o, por el contrario, se precisa de un dolo especial que la complemente? A nuestro entender, una correcta interpretación del Código obliga a concluir que la causal del artículo $160 \mathrm{~N}^{\circ} 6$ CT exige una claramente una conciencia y una voluntad de perjudicar. En palabras del mismo Código, se requiere expresamente de intencionalidad. Más allá del quantum, la intencionalidad es un ingrediente esencial a objeto de acreditar la gravedad de la conducta ${ }^{36}$ así como para reflejar una infracción a los deberes básicos de toda relación laboral ${ }^{37}$. Por ello, la redacción utilizada por el Código no deja lugar a dudas, aun cuando en épocas pretéritas existió alguna discusión jurisprudencial en torno a si este tipo de causales abarcaba también a los actos meramente imprudentes ${ }^{38}$. No obstante, en la actualidad esta última

34 Cruz Villalón, Jesús (2009), Compendio de Derecho del Trabajo, 2a edición. Madrid: Tecnos, 576 pp., p. 385.

35 Desde una perspectiva general, camara botia, Alberto (1997), "El carácter 'culpable' del incumplimiento del trabajador en el despido disciplinario". En Javier Gárate Castro (director), Cuestiones Actuales sobre el despido disciplinario. Santiago de Compostela: Universidad de Santiago de Compostela, 33-40 pp. pp. 33 y ss.

36 Gómez Abelleira (2009) 278.

37 Agra Viforcos, Beatriz (2011), "Daños ocasionados por el trabajador al material de la empresa”. Aranzadi Social Vol. $4 \mathrm{~N}^{\circ} 1$ (2011), pp. 67-73, p. 69.

38 Bajo la vigencia del Código de 1987, y ante causales que contenían redacciones análogas, la doctrina de los tribunales de justicia se encontraba dividida. Una corriente jurisprudencial consideraba que los actos meramente imprudentes, pero perjudiciales, sí podían ser sancionados como causa disciplinaria. Ese fue el criterio que siguió, por ejemplo, la sentencia de la Corte de Apelaciones de Santiago. 30 de septiembre de 1986. Rol No 1596-86. Recurso de Apelación. Caratulado "Urcullu con Transportes Transautos". GJ N 75 (1986), p. 69: "1.- (el trabajador) fue despedido (...) conforme la causal prevista en el artículo $15 \mathrm{~N}^{\circ}$ 3 del Decreto Ley $\mathrm{N}^{\circ} 2.200$, esto es, por 'comisión de actos que produzcan la destrucción de materiales, instrumentos o productos de trabajo o mercaderías, o disminuyan su valor o causen su deterioro'. (...). 4.- Que en el contexto que se ha planteado la causal invocada para el despido, corresponde analizar el verdadero sentido y alcance que tiene, en función del término de una relación laboral. En efecto, no se trata, y el legislador en parte alguna lo ha señalado, que el trabajador ejecute los hechos constitutivos de la causal, en forma intencional, de propósito. Tal conducta daría lugar a una situación de proyecciones diferentes. 
alternativa no es factible ya que los actos culposos están recogidos en el $\mathrm{N}^{\circ} 5$ del artículo $160 \mathrm{CT}$; y ha sido la propia jurisprudencia la que se ha encargado de separar el requisito de intencionalidad de la simple culpa ${ }^{39}$. De esta forma, en la ocurrencia de la hipótesis establecida en el artículo $160 \mathrm{~N}^{\circ} 6 \mathrm{CT}$ debe concurrir un dolo genérico que refleje conocimiento y voluntad de provocar un perjuicio material en bienes muebles o inmuebles del empleador (animus dommandi o nocendi) ${ }^{40}$. Si no se exigiese

En la especie, solo se requiere que haya existido negligencia culpable, vale decir, falta de esmero y cuidado en la ejecución del hecho". Otra corriente asimilaba estas conductas a supuestos claramente intencionales. Ese fue el caso resuelto por la sentencia de la CORTE DE Apelaciones de Antofagasta. 7 de noviembre de 1983. Rol N² 261. Extracto disponible en Thayer Arteaga, William, y Rodríguez Alvarado, Andrés (1988). Código del Trabajo y Legislación Social. Santiago: Editorial Jurídica de Chile/Editorial Jurídica Ediar ConoSur Ltda., 609 pp., p. 343: "Si el trabajador no tuvo el ánimo de perjudicar a la empresa porque los daños que se produjeron a la máquina que operaba se debieron a un accidente que no le es imputable (...), su despido ha sido injustificado". En igual sentido, sentencia de la CorTe de Apelaciones Pedro Aguirre Cerda. 23 de junio de 1987. Rol N 70-87. Caratulado "Celis con Sociedad Agrícola Mondin". Extracto disponible en Thayer Arteaga, William, y Rodríguez Alvarado, Andrés (1988). Código del Trabajo y Legislación Social. Santiago: Editorial Jurídica de Chile/Editorial Jurídica Ediar ConoSur Ltda., 609 pp., p. 344: "El legislador quiso sancionar la comisión de diversos actos delictivos perpetrados contra la normalización de las obligaciones laborales, los bienes de las empresas, sus materiales, productos, instrumentos de trabajo, etc., sancionando su comisión con la expiración inmediata del contrato de trabajo y sin derecho a indemnización alguna (...). En el caso de autos no aparece que se haya cometido la causal invocada contra el demandante puesto que si bien se estableció que este subió a un tractor y lo hizo moverse chocándolo contra uno cabezales y dañando algunas matas frutícolas, no se acreditó que estos perjuicios hayan sido causados intencionalmente y con ánimo delictivo". Ciertamente, la redacción utilizada por el Código de 1987 para este tipo de figuras excedía ampliamente la lógica meramente contractual del vínculo laboral, cuestión que dificultaba una interpretación más acorde con un sistema democrático de relaciones laborales. En este contexto, la Ley $\mathrm{N}^{\circ} 19.010$ vino a resolver esta dificultad, consagrando una causal que circunscribía la infracción al ámbito del contrato de trabajo e incorporaba de forma expresa el elemento de la intencionalidad en lo que respecta a los perjuicios provocados por el trabajador en contra del empleador.

39 Véase, en este sentido, la sentencia de la Corte de Apelaciones de Concepcion. 6 de junio de 2003. Rol N² 24-2003. Recurso de Apelación deducido por Consorcio Febrag S.A. y otros (disponible en www.poderjudicial.cl), la cual rechaza la posibilidad de asimilar en este caso la culpa grave con el dolo: “2) (...). No es aceptable la tesis de los demandados en orden a que es suficiente para que quede configurada dicha causal que el trabajador haya actuado con imprudencia temeraria o negligencia inexcusable, fundados en que a su juicio la ley en ese caso equipara la culpa grave al dolo. Y esto no es así, porque si bien en materia civil la culpa grave o lata equivale al dolo, según lo dispone el artículo 44 del Código Civil, ello se refiere más bien a los efectos del acto, a las consecuencias jurídicas que la ley asigna a la conducta ejecutada con culpa grave, asignándole los mismos que si se hubiese realizado con dolo. Pero en materia laboral la ley exige claramente intencionalidad en el acto que el trabajador ejecute en perjuicio del empleador, tanto porque la ley laboral es especial y priman sus normas sobre las reglas generales, como porque de haber querido el legislador asimilar la culpa grave al dolo lo habría así dicho expresamente, pues siendo el legislador uno solo no ha podido ignorar que en el derecho común consagró esa equiparación”.

40 Walker Errázuriz (2003) p. 409, quien reafirma la tesis de que esta causal no basta la despreocupación o la falta de atención del trabajador. Un criterio similar, en el plano jurisprudencial, en la sentencia de la CS, Rol No 2081-2001, p. 176, que rechaza aplicar la causal 
intencionalidad, entonces sería factible alegar que los meros descuidos, las negligencias simples o las desidias del trabajador no deben ser soportados por el empleador en virtud de la ajenidad. En la misma perspectiva, la intencionalidad exigida por la causal permite separar lo que son conductas más propias de una falta de probidad o de incumplimiento grave de obligaciones, de aquellas a que se refiere el artículo $160 \mathrm{~N}^{\circ} 6 \mathrm{CT}$. Dicho de otra manera, aquí no basta que los hechos que se le imputan al trabajador constituyan mera falta de probidad o un incumplimiento contractual, como si todas esas figuras fuesen expresiones de una misma realidad ${ }^{41}$. Por el contrario, lo que exige el Código en este caso es un tipo especial de conducta fundado en una intencionalidad específica de perjudicar.

La existencia de un dolo determinado en orden a provocar perjuicio permite dejar de lado la posibilidad de que el texto legal esté exigiendo la búsqueda de un provecho propio por parte del trabajador, ya que la falta se produce independientemente de si ha existido enriquecimiento para su autor o para un tercero. Asimismo, en algunos casos la jurisprudencia ha aplicado una especie de presunción de conocimiento del eventual perjuicio (más propio de la culpa que del dolo), a efectos de configurar la causal. Ello ocurrió, por ejemplo, con la sentencia de la CORTE SUPREMA de 8 de enero de 1998, en la cual se llegó a la conclusión que "por su condición de técnico eléctrico y jefe del departamento de mantención no podía menos que conocer las consecuencias que de su comportamiento derivarían con relación al material afectado" 42 .

en el caso de un trabajador que se desempeñaba como chofer de buses, y que en tal condición participó en un accidente automovilístico mientras realizaba sus labores embistiendo por la parte trasera a un vehículo menor causando daños (considerando tercero). También, sentencia de la CAP de La Serena, Rol N 154-2010, la cual parte de la base que el artículo $160 \mathrm{~N}^{\circ} 6 \mathrm{CT}$ "presume intencionalidad del trabajador, esto es, la presencia de instinto dańino en causar perjuicios en la propiedad privada del empleador; por lo que para su configuración debe existir manifiesta y evidentemente una intencionalidad del trabajador en la producción del perjuicio"; y sentencia de la Corte de Apelaciones de Coyhaique. 14 de octubre de 2009. Rol N²8-2009. Recurso de Apelación deducido por Andrés Marcelo Pincheira Stambuk. Disponible en www.poderjudicial.cl: "OCTAVO: (...) lo ocurrido fue un accidente, un descuido muy grande, situación esta que el legislador previene expresamente en la causal de despido del artículo $160 \mathrm{~N}^{\circ}$, cuando exige que para que se configure la respectiva causal de actos, omisiones o imprudencias temerarias, solo el descuido o imprudencia del trabajador que las ha ocasionado, pero no es el caso de la causal de autos -perjuicio material causado intencionadamente, en que el legislador exige algo más, a diferencia de la causal anterior, porque se requiere en este caso que haya una intención de causar perjuicio, no siendo bastante un descuido o negligencia-, porque es indispensable que la conducta del trabajador, sus actos, estén encaminados deliberadamente a causar daño (...)". Sentencia de la CAP de Santiago, Rol N D-977-84-T, p. 168. Aunque no referida específicamente al núcleo de la causal, también se puede consultar la sentencia de la CORTE DE Apelaciones de Santiago. 30 de marzo de 1987. Rol N 121-87. Recurso de Apelación. Caratulado "Arriaza con Pardo". GJ Nº 81 (1987), p. 88.

42 Sentencia de la CS. Rol N $\mathrm{N}^{\circ} 4571-96$, p. 1. Un criterio de similar orientación, aunque no se refiere específicamente a la causal del artículo $160 \mathrm{~N}^{\circ} 6 \mathrm{CT}$, puede consultarse en la sen- 
Claramente, la redacción utilizada por el Código no pretende asimilar el dolo penal con la voluntariedad de la conducta ilícita laboral. Como ya se ha dicho, la causal del artículo $160 \mathrm{~N}^{\circ} 6$ CT no implica la comisión de un delito penal de daño. Por el contrario, lo que subyace en la norma del Código del Trabajo es una intención lesiva que la mayor parte de las veces será evaluada por la magnitud del daño ${ }^{43}$. De igual forma, la presencia de un dolo perjudicial no exige la concurrencia de un ánimo de venganza ${ }^{44}$. Tampoco se requiere una especial intención de impedir el ejercicio del poder de dirección por parte del empleador. Más aun, perfectamente el daño se puede provocar por simple diversión, o por pura maldad. Lo relevante es que exista intencionalidad (no mera imprudencia) en la comisión del acto perjudicial ${ }^{45}$, cuestión que permite vincular la causal disciplinaria con una típica hipótesis de mala fe subjetiva.

Por último, cabe tener presente que, en el caso del empleador, para que este pueda tener la condición de perjudicado resulta esencial que el daño se haya provocado sin su consentimiento. La acción intencional

tencia de la Corte de Apelaciones de Talca. 25 de octubre de 2002. Recurso de Apelación. Rol N 1680-2002. Caratulado “Suárez Abel con González y Lara Ltda.”. GJ N 271 (2003), p. 173. En dicho fallo, la Corte concluyó que la circunstancia que el demandante hubiese manejado un vehículo de su empleador, "en forma reiterada sin contar con la respectiva licencia para ello, (supone) grave falta la que permite calificar a su despido como justificado, ya que la conducta del demandante, al haber quedado en la imposibilidad legal de cumplir con su trabajo y de no haber dado conocimiento en forma oportuna a su empleador, no solo en sí es una falta grave, sino que, además, significó como se ha dicho, haber puesto a la demandada en la posibilidad de haber sufrido graves dańos (...)".

43 Diéguez, Gonzalo (1969), La fidelidad del trabajador en LCT. Pamplona: Ediciones Universidad de Navarra, 88 pp., p. 47.

$44 \quad$ En esta línea, Etcheberry (1976) 369.

45 Sentencia de la CAP De SAntiago, Rol N 6854-2007: “Tercero: (...). El legislador exige intencionalidad en el acto que el trabajador ejecute en perjuicio del empleador lo que sin lugar a dudas excluye la imprudencia temeraria o negligencia inexcusable”. En similar sentido, sentencia de la CAP de La Serena, Rol N 154-2010: "Quinto: (...). Que en la especie, (...) los elementos probatorio no logran formar convencimiento de los presupuestos que configuran la aludida causal de desvinculación laboral, especialmente, la circunstancia que la actora haya provocado intencionalmente los perjuicios materiales que la demandada invoca, ya sea en las instalaciones, maquinarias, instrumentos o útiles de trabajo, en los productos o mercaderías, ni que la conducta atribuida a la actora haya menoscabado o haya hecho cesar la actividad comercial del establecimiento en que prestaba sus servicios, por lo que el referido motivo de despido aparece indebidamente aplicado, más todavía, si el sustento fáctico esgrimido por la empleadora no se aviene con dicha causal, por cuanto no se le ha imputado a la trabajadora que haya sido ella quien maliciosamente procedió a contaminar con hongos el pan, ni que deliberadamente haya puesto al alcance de insectos (hormigas), los pollos destinados al consumo de la clientela de la empleadora, toda vez que esta solo ha sustentado la indicada causal, en la circunstancia de no haber tomado la demandante las medidas de resguardo para evitar el mal estado de los productos alimenticios”. En el plano doctrinal, véase además Lizama Portal (2003) 182. Un criterio distinto a lo planteado, puede consultarse en la sentencia de la Corte Suprema. 2 de diciembre de 1998. Rol N 4053-98. Recurso de Casación en el Fondo. Caratulado "Vidal Fredes, Hernán con Fábrica de". Disponible en www.poderjudicial.cl. En este caso, la jurisprudencia concluyó que se justifica la aplicación de la causal en caso de que exista error del trabajador en el proceso productivo. 
del trabajador tendiente a perjudicar, y que cuenta con el acuerdo de la contraparte, no alcanza para reprochar de antijuridicidad el acto ya que el propio ordenamiento jurídico le reconoce al empleador titular la capacidad de disponer de sus bienes, incluso de destruirlos ${ }^{46}$.

\section{6) LOS OBJETOS MATERIALES PROTEGIDOS: INSTALACIONES, MAQUINARIAS, HERRAMIENTAS, ÚTILES DE TRABAJO, PRODUCTOS O MERCADERÍAS}

El Código chileno pone énfasis en que el perjuicio debe hacerse efectivo en instalaciones, maquinarias, herramientas, útiles de trabajo, productos o mercaderías. La referencia es amplia, y de cierta forma denota una vocación generalista como si se intentara enumerar a título ejemplar $^{47}$. En todas estas hipótesis subyace la idea de bienes vinculados a la actividad productiva, cuestión que permite excluir los atentados a otros bienes de titularidad del empleador, pero ajenos al ámbito laboral. La palabra instalaciones busca hacer referencia al recinto o lugar acondicionado, que cuenta con todas las cosas necesarias para cumplir la finalidad productiva que lleva adelante el empleador. La voz maquinarias, por su parte, se vincula no solo con el conjunto de máquinas que se usan para un fin determinado sino que también y sobre todo con el conjunto de piezas que componen un mecanismo y que sirven para poner en funcionamiento un aparato o un bien determinado de la empresa. Muy unido a lo anterior, las herramientas dicen relación con objetos de cualquier clase, necesarios para el desempeńo de la actividad. En cuanto a los útiles de trabajo, todo indica que el legislador quiere hacer referencia a aquellos bienes que el trabajador utiliza en el desempeńo de su actividad y que por cierto tienen como titular al empleador. Finalmente, las mercaderías o productos se relacionan con los frutos, bienes o mercancías del empleador y que son susceptibles de valor comercial ${ }^{48}$.

Como puede apreciarse, el listado de alternativas que ofrece el Código deja en evidencia que el objeto material del perjuicio será de preferencia (aunque no exclusivamente) una cosa de carácter corporal y que sea

\footnotetext{
46 Véase esta hipótesis, desde una perspectiva penal, pero aplicable al ámbito laboral, en GARRIdo MontT, Mario (2003), Derecho Penal. T. II, 3a edición. Santiago: Editorial Jurídica de Chile, 478 pp., p. 124.

47 Parte de la doctrina comparada ha criticado el uso de estas referencias genéricas, ya que en caso alguno la enumeración podría significar una exclusión de responsabilidad por otros perjuicios a bienes diferentes. Durán López, Federico (1979), "Las garantías del cumplimiento de la prestación laboral: el poder disciplinario y la responsabilidad contractual del trabajador". RPS No 123, 5-63 pp., p. 56.

48 Véase el alcance de alguna de estas expresiones en el Código del Trabajo de 1931, en Sото CaLderón (1961) 122.
} 
susceptible de sufrir una destrucción, deterioro o inutilización. Desde esta perspectiva, las referencias legales pueden ser reconducidas a la idea de que los atentados deben afectar bienes muebles (semovientes o inanimados) e inmuebles. Por cierto, también podrán formar parte de los bienes protegidos los animales, los que sin lugar a dudas pueden ser valorados económicamente. También se encuentran dentro de la hipótesis legal de bienes afectados, los documentos (archivos o registros) que en cuanto tales o por su materialidad sí son valiosos. Pero en todos estos casos, resulta primordial que el bien afectado se encuentre conectado con la actividad laboral del empleador.

\section{7) LA ESPECIAL SITUACIÓN DE LOS DAÑOS INFORMÁTICOS}

Un supuesto especial de perjuicio, se produce en el caso de los bienes informáticos. Durante los últimos años en Chile, y en especial después de la dictación de la Ley $\mathrm{N}^{\circ} 19.223$ (DO de 7 de junio de 1993), la figura del sabotaje informático o de la criminalidad informática ha adquirido creciente relevancia jurídica. De allí que, en materia laboral, la hipótesis del artículo $160 \mathrm{~N}^{\circ} 6$ CT puede perfectamente asimilarse a daños que el trabajador provoque intencionalmente en datos, programas informáticos o documentos electrónicos ${ }^{49}$. De igual modo, se pueden extender a los perjuicios provocados sobre los elementos físicos de carácter computacional, tales como monitores, grabadoras, discos duros u otros elementos de análoga naturaleza. Como se puede observar, no solo se sanciona el quebranto material del objeto sino que, también, el daño funcional.

El sabotaje informático cabe dentro de las figuras de daño, pero ciertamente amplía su aplicación a objetos incorporales o inmateriales ${ }^{50}$. Ello implica apartarse de la regla general que subyace en el núcleo definitorio del artículo $160 \mathrm{~N}^{\circ} 6 \mathrm{CT}$, aun cuando habrá que aceptar que en estos casos es de usual aplicación la causal disciplinaria.

En los casos a que se hace referencia, el perjuicio material puede verificarse en la destrucción o desaparición completa de los datos, programas o documentos de soporte computacional. De igual forma, el perjuicio se puede producir en todas aquellas situaciones en que exista una desaparición o perturbación relevante de la capacidad funcional del bien. En este orden de ideas, el sabotaje electrónico se puede llevar a cabo mediante variadas alternativas, tales como el uso de programas destructivos, el abuso de hardware defectuoso o simplemente mediante la terminación del

\footnotetext{
49 Sobre el particular, véase la hipótesis contemplada en el artículo $3^{\circ}$ de la Ley $\mathrm{N}^{\circ} 19.223$, el cual sanciona al "que maliciosamente altere, dańe o destruya los datos contenidos en un sistema de tratamiento de información”.

50 Por todos Gómez Abelleira (2009) 278.
} 
sofware ${ }^{51}$. También se ejecutaría el daño mediante el denominado ciberpunking, los crash programs, o los virus programs, entre un sinnúmero de otras alternativas ${ }^{52}$. Y todo ello traería como consecuencia un perjuicio consistente en destruir o inutilizar un sistema de tratamiento de información, cuestión que cuadra perfectamente con la hipótesis del artículo 160 $\mathrm{N}^{\circ} 6$ CT. Lo anterior se ve reafirmado en la figura que sanciona el artículo $1^{\circ}$ de la Ley $\mathrm{N}^{\circ}$ 19.223: "El que maliciosamente destruya o inutilice un sistema de tratamiento de información o sus partes o componentes, o impida, obstaculice o modifique su funcionamiento, sufrirá la pena de presidio menor en su grado medio a máximo".

\section{III) CONCLuSiones}

A partir de las explicaciones anteriores, es posible extraer las siguientes conclusiones:

1. Contrariamente a lo que se ha señalado doctrinaria y jurisprudencialmente, la causal del artículo $160 \mathrm{~N}^{\circ} 6 \mathrm{CT}$ tiene una regulación más amplia que el simple sabotaje. Sus contornos normativos permiten aplicarla a atentados de cierta entidad que provocan daños materiales sobre bienes concretos del empleador así como sobre el valor de uso de los mismos (e incluso su inutilización).

2. La causal extintiva en modo alguno se asimila al mero delito penal de daños. La configuración laboral de esta figura es más genérica y cubre cualquier acto intencional del trabajador que traiga como consecuencia un perjuicio relevante sobre bienes de cierta entidad del empleador. Desde esta perspectiva, hay atentados que no constituyen delito, pero que eventualmente sí pueden configurar una infracción al estilo del artículo $160 \mathrm{~N}^{\circ} 6 \mathrm{CT}$.

3. Para que se configure la infracción, el Código no solo exige voluntariedad de la conducta sino que, además, intención dolosa. Este dolo no es el mismo que se exige en materia penal, pero desde luego permite separar la mera ejecución de actos carentes de intención dañosa de aquellos en que el acto ha estado precedido de una clara intención de perjudicar patrimonialmente al empleador. De esta forma, la figura extintiva se aparta del diseño general de varias causales disciplinarias de despido en que el ilícito laboral se estructura a partir de la simple concurrencia de voluntariedad.

4. La causal del artículo $160 \mathrm{~N}^{\circ} 6 \mathrm{CT}$ participa de la misma exigencia de gravedad que subyace en todas las causas disciplinarias. Por ello,

\footnotetext{
$51 \quad$ Corcoy Bidasolo (2011) 589.

52 Andrés Domínguez (2011) 434.
} 
en principio, los actos irrelevantes o de baja entidad no están cubiertos por el diseño legal. Con todo, la gravedad no se mide exclusivamente por el monto económico del detrimento, sino que también por el quebrantamiento irrestaurable del vínculo de confianza. Y en esta última perspectiva, adquieren importancia para medir la gravedad factores tan disímiles como la naturaleza del cargo o la incrustación del bien deteriorado dentro del ciclo productivo. Más aun, la propia intencionalidad es un factor relevante para medir la gravedad de la conducta.

\section{BIBLIOGRAFÍA}

- Agra Viforcos, Beatriz (2010), "Obligaciones indemnizatorias del trabajador a su empresario. Supuestos de hecho a la luz de los pronunciamientos judiciales". AL N ${ }^{\circ}$, pp. 1-24.

- Agra Viforcos, Beatriz (2011), "Daños ocasionados por el trabajador al material de la empresa”. Aranzadi Social Vol. $4 \mathrm{~N}^{\circ} 1$, pp. 67-73.

- Aguilera Izquierdo, Raquel (1997), Las causas del despido disciplinario y su valoración por la jurisprudencia. Pamplona: Aranzadi, 323 pp.

- Alarcón Caracuel, Manuel Ramón (1986), "La ajenidad en el mercado: un criterio definitorio del contrato de trabajo". REDT No 28, pp. 495-544.

- Andrés Domínguez, Ana Cristina (2011), "Los daños". En Alvarez García, Javier (director): Derecho Penal español. Parte Especial, T. II. Valencia: Tirant lo Blanch, pp. 417-443.

- Cabanellas, Guillermo (1988), Tratado de Derecho del Trabajo, T. II, Vol. 3, 3a edición. Buenos Aires: Heliasta, 539 pp.

- Camara Botia, Alberto (1997), "El carácter 'culpable' del incumplimiento del trabajador en el despido disciplinario". En Gárate Castro, Javier (director), Cuestiones Actuales sobre el despido disciplinario. Santiago de Compostela: Universidad de Santiago de Compostela, pp. 33-40

- Corcoy Bidasolo, Mirentxu (1990), "La protección penal del sabotaje informático. Especial consideración de los delitos de daños". La Ley (1990), T. I, pp. 1000-1016.

- Corcoy Bidasolo, Mirentxu (2011), "Los daños". En Corcoy, Mirentxu, y Mir, Santiago, Comentarios al Código Penal. Valencia: Tirant lo Blanch, pp. 584-594.

- Cremades, Bernardo María (1969), La sanción disciplinaria en la empresa. Madrid: Instituto de Estudios Políticos, 312 pp. 
- Cruz Villalón, Jesús (2009), Compendio de Derecho del Trabajo, 2a edición. Madrid: Tecnos, 576 pp.

- De Buen Lozano, Néstor (1992), Derecho del Trabajo, T. II, 9a edición. México: Porrúa, pp. 890.

- Diéguez, Gonzalo (1969), La fidelidad del trabajador en LCT. Pamplona: Ediciones Universidad de Navarra, 88 pp.

- Durán López, Federico (1979), "Las garantías del cumplimiento de la prestación laboral: el poder disciplinario y la responsabilidad contractual del trabajador". RPS $\mathrm{N}^{\circ} 123,5-63$ pp.

- Etcheberry, Alfredo (1976), Derecho Penal, T. III, 2a edición. Santiago: Editora Nacional Gabriela Mistral, 490 pp.

- Gaete Berríos, Alfredo (1966), Tratado de Derecho del Trabajo y Seguridad Social, T. III. Santiago: Editorial Jurídica de Chile, 213 pp.

- Gamonal Contreras, Sergio, y Guidi Moggia, Caterina (2011), Manual de Contrato de Trabajo. Santiago: Abedelo Perrot/ LegalPublishing Chile, 337 pp.

- Garrido Montt, Mario (2003), Derecho Penal, T. II, $3^{\text {a }}$ edición. Santiago: Editorial Jurídica de Chile, 478 pp.

- Goerlich Peset, José María (2011), "Particularidades de la responsabilidad indemnizatoria del trabajador por los dańos causados a la empresa en el desarrollo de la prestación laboral: un intento de explicación". REDT No 152, 945-972 pp.

- Gómez Abelleira, Francisco Javier (2009), "Las causas disciplinarias del despido", 2a edición. En Sempere Navarro, Antonio-Vicente (director): El despido. Pamplona: AranzadiThomson Reuters, pp. 146-315.

- Izquierdo Orrego, Cristóbal (2006), "Comisión por omisión. Algunas consideraciones sobre la injerencia como fuente de la posición de garante". RCHD Vol. $33 \mathrm{~N}^{\circ} 2$, pp. 329-343.

- Lizama Portal, Luis (2003), Derecho del Trabajo. Santiago: LexisNexis, 224 pp.

- Miñambres Puig, César (1985), El Centro de Trabajo. Madrid: Servicio de Publicaciones Ministerio de Trabajo y Seguridad Social, $251 \mathrm{pp}$.

- Soto Calderón, Juan Carlos (1961), Derecho Penal del Trabajo. Santiago: Editorial Jurídica de Chile, $161 \mathrm{pp}$.

- Thayer Arteaga, William, y Novoa Fuenzalida, Patricio (1998), Manual de Derecho del Trabajo, T. III, $3^{a}$ edición. Santiago: Editorial Jurídica de Chile, 335 pp.

- Thayer Arteaga, William, y Rodríguez Alvarado, Antonio (1988), Código del Trabajo y Legislación Social, T. I. Santiago: Editorial Jurídica de Chile/Editorial Jurídica Ediar ConoSur Ltda., 609 pp. 
- Walker Errázuriz, Francisco (1990), Terminación del contrato de trabajo. Santiago: Cepet, 302 pp.

- Walker Errázuriz, Francisco (2003), Derecho de las Relaciones Laborales, $1^{\text {a }}$ edición. Santiago: Editorial Universitaria, 718 pp.

- Zelaya Etchegaray, Pedro (1995), La responsabilidad civil del empresario por los daños causados por su dependiente. Pamplona: Aranzadi, 695 pp.

\section{JURISPRUdenCia CitAdA}

- Corte Suprema. 5 de enero de 1998. Rol No 4571-96. Recurso de Casación en el Fondo. Caratulado "Viveres Sánchez con Deves Rojas y Cía. Limitada". RDJ T. XCV, sección tercera (1998), p. 1.

- Corte Suprema. 2 de diciembre de 1998. Rol No 4053-98. Recurso de Casación en el Fondo. Caratulado "Vidal Fredes, Hernán con Fábrica de". Disponible en www.poderjudicial.cl

- Corte Suprema. 21 de junio de 2001. Rol No 2081-2001. Recurso de Casación en el Fondo. Caratulado "Tapia Saavedra con Empresa de Buses". GJ No 252 (2001), p. 173.

- Corte Suprema. 31 de marzo de 2004. Rol No 1053-2003. Recurso de Casación en el Fondo. Caratulado "Fuentes Pezoa con Ecokorp Ltda.". GJ No 286 (2004), p. 293.

- Corte de Apelaciones de Santiago. 26 de julio de 1984. Rol $\mathrm{N}^{\circ}$ D-977-84-T. Recurso de Apelación. Caratulado "Catricura con Planificadora Huelén". GJ N 49 (1984), p. 168.

- Corte de Apelaciones de Santiago. 30 de septiembre de 1986. Rol N ${ }^{\circ}$ 1596-86. Recurso de Apelación. Caratulado "Urcullu con Transportes Transautos". GJ N 75 (1986), p. 69.

- Corte de Apelaciones de Santiago. 30 de marzo de 1987. Rol N ${ }^{\circ}$ 121-87. Recurso de Apelación. Caratulado "Arriaza con Pardo". GJ $\mathrm{N}^{\circ} 81$ (1987), p. 88.

- Corte de Apelaciones de Santiago. 9 de octubre de 2008. Rol $\mathrm{N}^{\circ}$ 6854-2007. Recurso de Apelación deducido por Redbus S.A. Disponible en www.poderjudicial.cl

- Corte de Apelaciones de Antofagasta. 7 de noviembre de 1983. Rol N ${ }^{\circ}$ 261. Extracto disponible en Thayer Arteaga, William, y Rodríguez Alvarado, Andrés (1988). Código del Trabajo y Legislación Social. Santiago: Editorial Jurídica de Chile/Editorial Jurídica Ediar ConoSur Ltda., 609 pp., p. 343.

- Corte de Apelaciones de Antofagasta. 10 de agosto de 2011. Rol $\mathrm{N}^{\circ}$ 145-2011. Recurso de Nulidad. Caratulado "Saavedra Zepeda con Ameco S.A.”. Disponible en www.poderjudicial.cl 
- Corte de Apelaciones de la Serena. 24 de diciembre de 2010. Rol No 154-2010. Recurso de Nulidad. Caratulado "Merińo Alfaro con Vicencio Auger Limitada". Disponible en www.poderjudicial.cl

- Corte de Apelaciones de Coyhaique. 14 de octubre de 2009. Rol $\mathrm{N}^{\circ}$ 28-2009. Recurso de Apelación deducido por Andrés Marcelo Pincheira Stambuk. Disponible en www.poderjudicial.cl

- Corte de Apelaciones Pedro Aguirre Cerda. 23 de junio de 1987. Rol No 70-87. Caratulado "Celis con Sociedad Agrícola Mondin". Extracto disponible en Thayer Arteaga, William, y Rodríguez Alvarado, Andrés (1988). Código del Trabajo y Legislación Social. Santiago: Editorial Jurídica de Chile/Editorial Jurídica Ediar ConoSur Ltda., 609 pp., p. 344.

- Corte de Apelaciones de Concepcion. 6 de junio de 2003. Rol $\mathrm{N}^{\circ}$ 24-2003. Recurso de Apelación deducido por Consorcio Febrag S.A. y otros. Disponible en www.poderjudicial.cl

- Corte de Apelaciones de Talca. 25 de octubre de 2002. Recurso de Apelación. Rol No 1680-2002. Caratulado "Suárez Abel con González y Lara Ltda.”. GJ N² 271 (2003), p. 173. 